Article

\title{
First Report of the Red Algal Genus Chondria C. Agardh (Rhodomelaceae, Rhodophyta) for the Marine Flora of Bangladesh
}

\author{
Md. Ariful Islam ${ }^{1, *}$, Mst. Zannatun Mauya ${ }^{2}$, S.M. Rafiquzzaman ${ }^{3}$, Md. Rashedul Islam ${ }^{4}$ \\ and Lawrence M. Liao ${ }^{1, *}$ \\ 1 Aquatic Botany Laboratory, Department of Bioresource Science, Graduate School of Biosphere Science, \\ Hiroshima University, Higashi-Hiroshima 739-8528, Japan \\ 2 Department of Fisheries Management, Bangladesh Agricultural University, Mymensingh 2202, Bangladesh; \\ 92mauya@gmail.com \\ 3 Department of Fisheries Biology and Aquatic Environment, Faculty of Fisheries, Bangabandhu Sheikh \\ Mujibur Rahman Agricultural University, Gazipur 1706, Bangladesh; rafiquzzaman@bsmrau.edu.bd \\ 4 Fisheries \& Marine Resource Technology Discipline, Khulna University, Khulna 9208, Bangladesh; \\ mrislam.ku99@gmail.com \\ * Correspondence: fisharif34@gmail.com (M.A.I.); 1liao@hiroshima-u.ac.jp (L.M.L.); \\ Tel.: +81-82-424-4375 (L.M.L.)
}

Received: 18 May 2019; Accepted: 18 June 2019; Published: 20 June 2019

\begin{abstract}
Epiphytic algae in mangrove forests contribute to high productivity in these unique mangrove ecosystems. A general survey of mangrove-associated macroalgae was conducted during February-March (dry season) and November-December (wet season) in the Sundarbans Mangrove Forest, Bangladesh. Different macroalgae were collected from mangrove pneumatophores, roots, and branches of trees. During this survey, a small and inconspicuous species of Chondria was encountered from the upper-middle of the intertidal zone in the Malancha River $\left(22^{\circ} 5^{\prime} 11.37^{\prime \prime} \mathrm{N}\right.$ and $89^{\circ} 13^{\prime} 12.37^{\prime \prime}$ E). External-internal anatomical traits were examined and the sample was identified as Chondria intertexta Silva, a new record for the algal flora of Bangladesh. Furthermore, its geographical distribution and some other ecological notes are also discussed.
\end{abstract}

Keywords: algae; epiphyte; mangrove pneumatophore; phycology; seaweed; taxonomy

\section{Introduction}

Epiphytic red alga (e.g., Caloglossa sp., Chondria sp.) are commonly found in the intertidal [1,2]. Most members of the genus Chondria (Rhodomelaceae, Ceramiales) occur in intertidal rocks, hard substrates, and solid objects however, they are rarely found in mangrove ecosystems [1,3-6] Agardh [7] established the red algal genus Chondria, which he characterized as having cartilaginous and filamentous thalli, with branches that are constricted at the base, and the main axes composed of five pericentral cells surrounding the axial cell. Other vegetative features useful for classifying and identifying Chondria species are habitat, size and color of thalli when alive, branching pattern, shape of superficial epidermal cells, and the presence (or absence) and shape of lenticular cell wall thickenings [3,4,8].

The Sundarbans, located on the border between Bangladesh and India, is the world's largest mangrove forest. The algal flora within the Sundarbans was first studied by Islam [9] who documented 35 benthic algae (Chlorophyceae (14 spp.), Cyanophyceae (9 spp.), Phaeophyceae (1 sp.), Rhodophyceae (7 spp.), and Xanthophyceae (4 spp.)). Later on, he described the ecology and taxonomy of marine algae from Bangladesh, and 165 species belonging to 77 genera classified within Chlorophyta (38 spp.), Chrysophyta (5 spp.), Cyanophyta (27 spp.), Phaeophyta (46 spp.), and Rhodophyta (49 spp.) [10]. 
Among all the mangrove-associated flora reported from Bangladesh, most of them belong to the Bostrychietum group. A recent catalog of 193 seaweed species from Bangladesh belonging to 94 genera associated with three major divisions (Chlorophyta-green algae, Phaeophyta-brown algae and Rhodophyta-red algae), including many from the Sundarbans (around 60 species), was published by Sarkar et al. [11]. The present report adds Chondria, a genus hitherto unreported from Bangladesh.

Guiry and Guiry [12] listed 78 species of Chondria that are currently accepted. Species of Chondria can be found attached to other algae, shells, rocks, and mangrove pneumatophores [3]. During a survey of mangrove-associated algae in the Sundarbans in Southwestern Bangladesh, an interesting Chondria species was collected growing on the prop roots and pneumatophores of mangroves that represents a new addition to the marine algal flora of Bangladesh. The material is identified as Chondria intertexta Silva, that has not been reported from the greater Bay of Bengal region. Furthermore, our findings represent the first species record from anywhere in the Indian Ocean region. This report provides the description of this species, and compares it morphologically with similar congeners.

\section{Materials and Methods}

Samples were collected during the low tide from the mangrove stands lining the banks of Malancha River $\left(22^{\circ} 5^{\prime} 11.37^{\prime \prime} \mathrm{N}\right.$ and $\left.89^{\circ} 13^{\prime} 12.37^{\prime \prime} \mathrm{E}\right)$ and nearby areas within the Sundarbans mangrove forest, Bangladesh, in February, March, November, and December 2018. Specimens were scraped from mangrove trunks and pneumatophores with a small knife, and followed by field-preservation in ethanol. Fifteen $C$. intertexta Silva specimens were pressed between herbarium papers and dried under the sun. Samples were brought to the Aquatic Botany Laboratory, Graduate School of Biosphere Science, Hiroshima University in Japan for further identification. For proper identification, the distinctive features of external morphology and internal anatomy of both vegetative and reproductive structures were examined and compared with the descriptions of Lee and Yoon [3], Nam [13], Sutti [1], and Sutti et al. [6]. Sections were made by hand using double-edged razor blades. Fresh mounts were prepared using unstained sections, and examined by stereo dissecting scope and compound light microscope (Nikon SMZ1500 and Nikon ECLIPSE E400). Photos were taken by a digital camera mounted on the microscope (Nikon DS-Fi1 and Inohara INOCAM-30U2CM). Brightness, contrast, and increasing image magnifications were made by using Adobe Photoshop 7. Voucher specimens are to be deposited in the Bangladesh National Herbarium, Dhaka.

\section{Results}

\section{Taxonomic Treatment}

Chondria intertexta P.C. Silva [14]: 204 Figures 1-3.

Homotypic synonym: Chondria intricata Okamura [15]: 180, pl. XCIX, Figures 10-18, invalid name (non (Lamouroux) C. Agardh [1]: xviii, nec Kützing [16]: 437)

Type locality: Aburatsubo and Enoshima (Prov. Sagami), Japan [15].

Specimens examined: AHC-24, AHC-25, AHC-26, AHC-27 (Malancha River, Sundarbans, Bangladesh, 26-27, 02, 2018).

References: Lee and Yoon [3]: 124, Figure 10A-E; Nam [13]: 165, Figure 131A,B, 132 A-F; Sutti [1]: 24, Figure 7A-F.

Distribution: Central Polynesia, Japan, Korea, Solomon Islands [12].

Description: Frond is 2.0-5.0 (3.0) cm long, $0.9-2.0 \mathrm{~cm}$ broad (Figure 1), pale brownish red in color, intricate, soft in texture, and adhering to object by haptera, which are issued on erect filaments at various intervals. Main axis is indistinct (Figure 2a), terete or cylindrical, more or less curved, with obtuse apices, more or less flexuous, and the branches issued radially in one or two orders (Figures 1c and 2a). Branches are irregular, $0.5-1.5 \mathrm{~cm}$ long, 800-1200 $\mu \mathrm{m}$ in diameter, and slightly or not constricted at the base. Short ramuli issued from branches are at irregular intervals, clavate, with obtuse or depressed apices, 350-1200 $\mu \mathrm{m}$ long and 200-450 $\mu \mathrm{m}$ wide. Epidermal cells in the upper (younger) 
part of the main axis are oval or ellipsoid with uneven outlines, and 25-40 $\mu \mathrm{m}$; secondary pit connection present between two proximate cells (Figure 3c). Axial cells, are 25-30 $\mu \mathrm{m}$ in diameter, surrounded by five pericentral cells that are $35-40 \mu \mathrm{m}$ in diameter and connected by pit connections. Pericentral cells are cylindrical, elongated radially at the beginning of formation and gradually becoming inflated, assuming a longitudinally cylindrical form as long as broad, with 2-3 adjacent cells present between the pericentral cells (Figure 3a). Cell wall thickenings were found in the pericentral and sub-cortical cells (Figure 3b). Radial spine-like structures were found in pericentral cells (Figure 3c), and were considerably rigid and elastic at the fine ends, cartilaginous, glossy, and somewhat slender and attenuated towards their fine and acute ends. The radial spine-form structure seems to be associated with a cell wall and is connected via secondary pit connection [3].

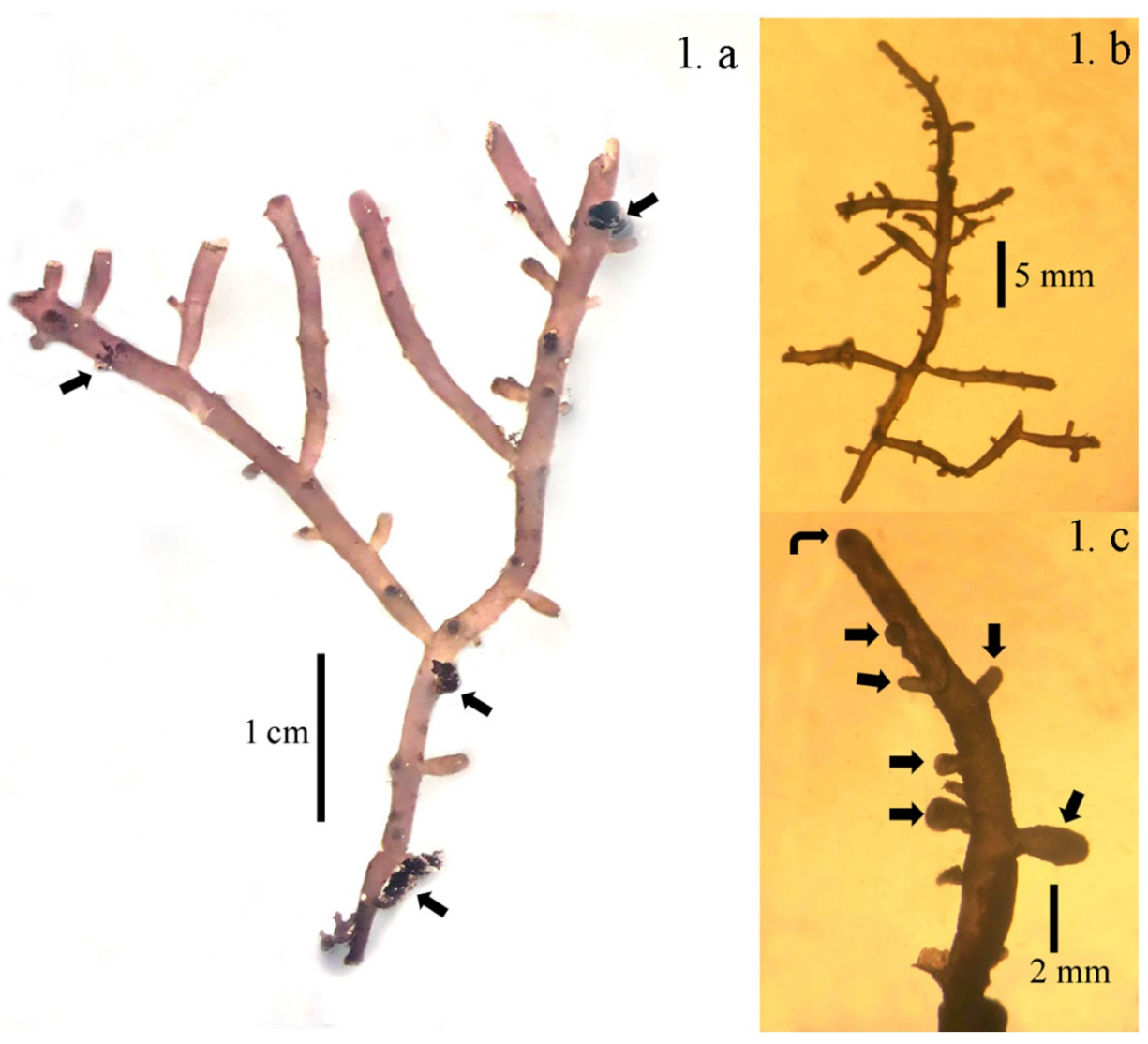

Figure 1. Chondria intertexta Silva. (a) Habit of the frond showing haptera (arrow) at main axis and lateral branches. (b) Habit of a thallus part shows typical and radially occurring branches. (c) Upper part of the thallus axis showing small ramuli (arrow) and obtuse apex (bent arrow). 




Figure 2. (a) Indistinct thallus shows rhizoidal attachment (arrow) and irregular branches. (b) Surface view of oval to ellipsoid epidermal cells at the upper middle part of the thallus. 

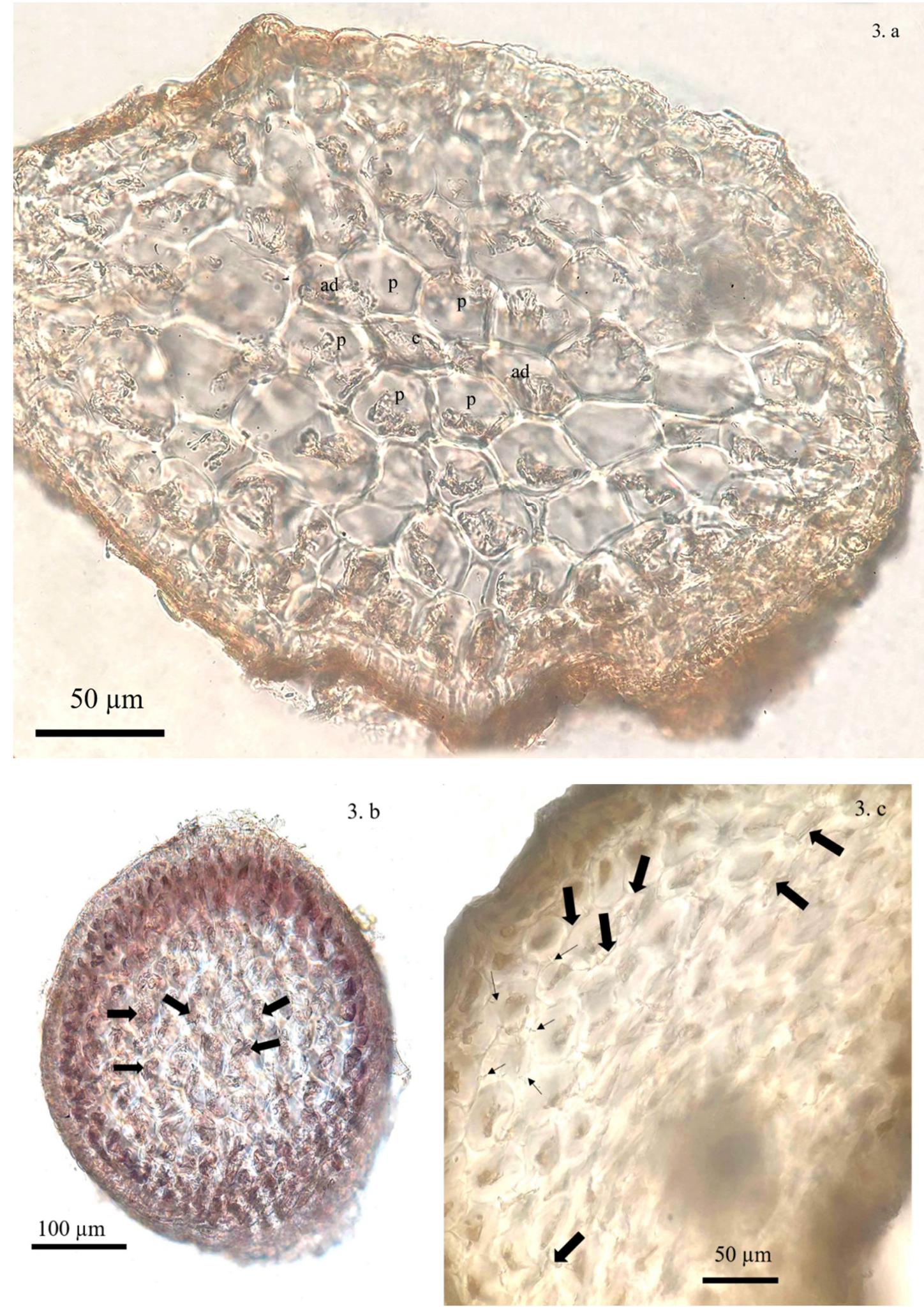

Figure 3. (a) Cross-section of main axis shows the axial cell (c) surrounded by five pericentral cells (p) and two adjacent cells (ad). Adjacent cells are connected to the axial cell through cell wall thickenings. (b) Cross section shows the cell wall thickening (arrow) in the pericentral cells and their sub-cortical cells. (c) Cross section shows the fine spine like structure (small arrow) around the pericentral cell region and connected with secondary pit connections (large arrow). 


\section{Discussion}

C. intertexta Silva was collected only during the dry season from a small population among complex bushes on mangrove pneumatophores in the upper-mid intertidal zone of Malancha river. The specimens were recorded at the upstream of the river together with Catenella caespitosa (Withering) L.M. Irvine, C. impudica (Montagne) J. Agardh, C. nipae Zanardini, Caloglossa. bengalensis (G. Martens) King \& Puttock, C. beccarii (Zanardini) De Toni, and C. stipitata E. Post. Plants cannot be detached without rupturing the thalli because they are attached at multiple intervals by haptera that are issued from every erect filament at several intervals, making the attachment of erect filaments firmly together in place (Figures 1a and 2a).

Okamura [15] first described this species as Chondria intricata from Aburatsubo and Enoshima (Sagami province, in present-day Kanagawa prefecture), Japan. However, Silva [14] proposed as a replacement name $C$. intertexta because $C$. intricata had been preempted by Agardh [7] and Kützing [16].

Color is considered a good identification feature to identify the thallus. Therefore, it should be kept in dark condition to preserve the color as much as possible ([1] Table 1). Discoloration occurs due to long light and sun exposure (discoloration slightly visible after soaking with water within $4-5 \mathrm{~h}$ ). Color alteration was not observed from either soaking with freshwater (tap water) or sterilized seawater (20-35 ppt) within 4-5 h. Irregular and radially branching patterns are common for Chondria, but branchlets are mainly formed from both sides of the main axes. The angle of divergence (branching angles) is not a suitable taxonomic character for this particular taxon as it can vary considerably for this genus [1]. On the other hand, apices and shape of branchlets can be useful tools to identify the Chondria species $[17,18]$. For example, acute apices and constriction can be found in C. arcuata Hollenberg, C. armata (Kützing) Okamura, C. crassicaulis Harvey, C. expansa Okamura, and C. lancifolia Okamura (Table 1). The shape of epidermal cells, cell arrangements, and pit connections can also separate the species of Chondria [3,4]. The oblong to ellipsoid shape of epidermal cells of $C$. intertexta can be used to separate it from other species (Table 1), however this varies in different thallus parts, therefore either the lower, middle, or upper middle part has been selected for surface viewing. For example, the epidermal cells of C. expansa Okamura are roundish polygonal in the apical part of branch, and elongated longitudinally into a linear form in the middle to lower part of the branch [3]. Cell wall thickenings in the pericentral cells and subcortical cells have been used to distinguish species as first suggested by Gordon-Mills and Womersley [19] and Gordon-Mills [20], as the form of cell wall thickenings and their presence or absence may be species-specific [3]. Cell wall thickenings in the pericentral cells and subcortical cells were frequently found in most species like C. crassicaulis, C. dasyphylla (Woodward) C. Agardh, C. expansa, and C. intertexta, while the rest of the species do not possess such cell wall thickenings (Table 1). The concentration, number, and abundance of cell wall thickenings also vary within a species depending on age; older thallus shows more cell wall thickenings [1]. The main axis is surrounded by 5 pericentral cells and 2-3 adjacent cells [1], which is a unique trait of Chondria. These adjacent cells are often defined as adventitious pericentral cells or sub-pericentral cells $[1,3,6]$. 
Table 1. A comparison of Chondria intertexta Silva with congeneric species of Chondria based on external-internal morphology and reproductive features.

\begin{tabular}{|c|c|c|c|c|c|}
\hline Characters & Chondria intertexta & C. arcuata & C. expansa & C. lancifolia & C. armata \\
\hline Habit of the plants & epiphytic & $\begin{array}{l}\text { epiphytic or rock or } \\
\text { calcified algae }\end{array}$ & epiphytic or epilithic & epiphytic & $\begin{array}{l}\text { attached to substrate } \\
\text { (root like branches) }\end{array}$ \\
\hline Thallus structure & terete, indistinct & terete, distinct & terete, indistinct & terete near base, indistinct & subcylindrical, distinct \\
\hline Height of the fronds $(\mathrm{cm})$ & $3-4$ & $1-2$ & $5-8$ & $3-6$ & $5-6$ \\
\hline Color of the fronds & pale brownish red & brownish red & reddish brown & dark red & pinkish red \\
\hline Apex of the plants & obtuse and depressed & obtuse and depressed & acute & acute & acute \\
\hline Ramuli at the thallus & $\begin{array}{c}\text { short } 250-400 \mu \mathrm{m} \text { broad, } \\
400-1300 \mu \mathrm{m} \text { long }\end{array}$ & rare & linear & linear & short \\
\hline $\begin{array}{c}\text { Epidermal cells on surface } \\
\text { view }\end{array}$ & $\begin{array}{l}\text { oblong to ellipsoid } 25-35 \\
\mu \mathrm{m} \text { broad, } 50-85 \mu \mathrm{m} \text { long }\end{array}$ & $\begin{array}{c}\text { ellipsoid to fusiform } \\
20-55 \mu \mathrm{m} \text { broad, } 45-100 \\
\mu \mathrm{m} \text { long }\end{array}$ & $\begin{array}{l}\text { roundish polygonal to } \\
\text { linear } 15-20 \mu \mathrm{m} \text { broad, } \\
20-45 \mu \mathrm{m} \text { long }\end{array}$ & $\begin{array}{l}\text { longish ellipsoid to } \\
\text { oblong } 15-30 \mu \mathrm{m} \text { broad, } \\
30-50 \mu \mathrm{m} \text { long }\end{array}$ & $\begin{array}{l}\text { longish to linear } 10-15 \mu \mathrm{m} \\
\text { broad, } 40-55 \mu \mathrm{m} \text { long }\end{array}$ \\
\hline Cell wall thickenings & present & absent & present & absent & absent \\
\hline Tetrasporangia & $\begin{array}{l}\text { no reproductive structure } \\
\text { observed during study } \\
\text { period }\end{array}$ & $\begin{array}{c}\text { borne in apical parts of } \\
\text { main axes and branches, } \\
\text { globose, } 90-100 \mu \mathrm{m} \text { in } \\
\text { diameter }\end{array}$ & $\begin{array}{c}\text { borne in middle to upper } \\
\text { parts of ramuli, } 100-120 \\
\mu \mathrm{m} \text { in diam. with } \\
\text { tetrahedral division. }\end{array}$ & $\begin{array}{c}\text { globose, } 120-130 \mu \mathrm{m} \text { in } \\
\text { diameter }\end{array}$ & no data \\
\hline Cystocarps & not found & unknown & no data & jar-form & no data \\
\hline References & present work and $[1,3-13]$ & {$[3,13]$} & {$[1,3-13]$} & {$[3,13]$} & [1] \\
\hline
\end{tabular}


Reproductive characters also provide a basis for identifying species, but reproductive structures are often not found. Tetrasporophytes of Chondria share typical characters such as tetrahedrally divided tetrasporangia borne on a pericentral cell [1]. The presence or absence of a cystocarpic spur, and shape of cystocarps, in female gametophytes have also been used as taxonomic characters for the identification of Chondria species [3,20]. In the case of male gametophytes, the origin, shape of spermatangial plate, and the number of sterile cells surrounding the spermatangial plate, are used as taxonomic features $[3,20,21]$. However, usually male plants are rarely found, and we did not observe such structures in our material or even female cystocarps.

Aside from its type locality in central Pacific coast of Japan, C. intertexta has been recorded from the warm temperate waters of Korea and in the tropical waters of the Solomon Islands and central Polynesia. This report extends its distribution farther west of the Japanese type locality into the Bay of Bengal in the Indian Ocean. This species may be more widespread than previously thought. It is seldom detected because of its inconspicuous nature among the turf epiphytic flora in mangrove forests. It is likely found in other mangrove areas in the Indo-West Pacific. It is a small, inconspicuous species forming turfs on mangrove pneumatophores together with other minute species which are often covered with a thin coat of mud causing them to be overlooked by inexperienced collectors. In fact, it is suggested to have a wider distribution throughout the tropical and warm temperate regions occurring mainly in the intertidal and subtidal zones $[3,22]$. It is therefore surprising to find this species, but the ecology and wider distribution made favorable in the study area where many turf-forming species including $C$. intertexta form close associations with host mangrove species, thereby contributing to the high primary productivity there.

\section{Conclusions}

Chondria intertexta Silva is newly recorded from the Sundarbans forest, Bangladesh, and represents a new genus and species record for the marine flora of Bangladesh. The discovery of $C$. intertexta in the Sundarbans is not surprising, but an interesting component for the ecology of Bay of Bengal. This species is likely cosmopolitan, currently reported for the first time from the Indian Ocean region. Further searches within the possible range of $C$. intertexta will likely reveal its wider distribution.

Author Contributions: Field work and specimen collections were assisted by M.Z.M., Sampling permission, local guidance, data compilation and other technical supports were performed by M.R.I. and S.M.R. The whole work was completed by the leading author M.A.I. The study, research design and manuscript revision was guided by leading author's thesis supervisor L.M.L.

Funding: Field work in Bangladesh was supported by a travel grant from the Graduate School of Biosphere Science, Hiroshima University, as well as the issuance of a permit from the Bangladesh Forests Department. Graduate research of the first author is made possible by a scholarship grant from the Monbukagakusho (MEXT-Japan Ministry of Education, Culture, Sports, Science and Technology).

Acknowledgments: Microphotographic equipment and assistance were kindly provided by Koichiro Kawai and Shaharior Arnob (Graduate School of Biosphere Science, Hiroshima University). Valuable field assistance was provided by Chayan Biswas (Khulna University).

Conflicts of Interest: The authors declare no conflict of interest.

\section{References}

1. Sutti, S. A morphological and phylogenetic study of the genus Chondria (Rhodomelaceae, Rhodophyta). Ph.D. Thesis, Hokkaido University, Sapporo, Japan, 2018.

2. King, R.J.; Puttock, C.F. Morphology and taxonomy of Caloglossa (Delesseriaceae, Rhodophyta). Aust. Syst. Bot. 1994, 7, 89-124. [CrossRef]

3. Lee, Y.; Yoon, S. Taxonomy of Chondria (Rhodophyta) in Korea. Algae 1996, 11, 107-139.

4. Tani, M.; Masuda, M. A taxonomic study of two minute species of Chondria (Ceramiales, Rhodophyta) from the north-western Pacific, with the description of Chondria econstricta sp. nov. Phycologia 2003, 42, 220-231. [CrossRef] 
5. Garbary, D.; Vandermeulen, H. Chondria pygmaea sp. nov. (Rhodomelaceae, Rhodophyta) from the Gulf of Aquaba, Red Sea. Bot. Mar. 1990, 33, 311-318. [CrossRef]

6. Sutti, S.; Tani, M.; Yamagishi, Y.; Abe, T.; Miller, K.A.; Kogame, K. Neochondria gen. nov. (Rhodomelaceae, Rhodophyta), a segregate of Chondria, including N. ammophila sp. nov. and N. nidifica comb. nov. Phycologia 2018, 57, 262-272. [CrossRef]

7. Agardh, C.A. Synopsis Algarum Scandinaviae; Berling: Lund, Sweden, 1817.

8. Bacci, D.S. Estudos taxonômicos do gênero Chondria (Ceramiales, Rhodophyta) no litoral dos estados de São Paulo de Espirito Santo, São Paulo, Brazil. Master's Thesis, Instituto de Botânica da Secretaria de Estado do Meio Ambiente, São Paulo, Brazil, 2005.

9. Islam, A.K.M.N. The algal flora of Sundarbans mangrove forest, Bangladesh. Bangladesh J. Bot. 1973, 2, 411-436.

10. Nurul Islam, A.K.M. Contribution to the Study of the Marine Algae of Bangladesh; Bibliotheca Phycologica; J. Cramer Verlag: Vaduz, Liechtenstein, 1976; p. 276.

11. Sarkar, M.S.I.; Kamal, M.; Hasan, M.M.; Hossain, M.I. Present status of naturally occurring seaweed flora and their utilization in Bangladesh. Res. Agric. Livest. Fish. 2016, 3, 203-216. [CrossRef]

12. Guiry, M.D.; Guiry, G.M. AlgaeBase. World-Wide Electronic Publication. National University of Ireland, Galway, 2019. Available online: http://www.algaebase.org (accessed on 19 June 2019).

13. Nam, K.W. Algal Flora of Korea. In Rhodophyta: Florideophyceae: Ceramiales: Rhodomelaceae: Laurencia, Chondrophycus, Palisada, Chondria; Marine Red Algae; National Institute of Biological Resources: Incheon, Korea, 2011; Volume 4, Number 3.

14. Silva, P.C. Remarks on algal nomenclature V. Taxon 1972, 21, 199-205. [CrossRef]

15. Okamura, K. Icones of Japanese Algae; Kazamashobo: Tokyo, Japan, 1912; Volume 2, pp. 167-186.

16. Kützing, F.T. Phycologia Generalis oder Anatomie, Physiologie und Systemkunde der Tangel; Brockhaus: Leipzig, Germany, 1843.

17. Kylin, H. Die Gattungen der Rhodophyceen; Gleerups: Lund, Sweden, 1956.

18. Taylor, W.R. Marine Algae of the Eastern Tropical and Subtropical Coasts of the Americas; University of Michigan Press: Ann Arbor, MI, USA, 1960.

19. Gordon-Mills, E.; Womersley, H.B.S. Cell wall thickenings in the taxonomy of Chondria and Husseyella (Rhodomelaceae, Rhodophyta) from southern Australia. Hydrobiologia 1984, 116-117, 224-226. [CrossRef]

20. Gordon-Mills, E. Morphology and taxonomy of Chondria tenuissima and Chondria dasyphylla (Rhodomelaceae, Rhodophyta) from European waters. Br. Phycol. J. 1987, 22, 237-255. [CrossRef]

21. Womersley, H.B.S. The Marine Benthic Flora of Southern Australia, Part IIID; Australian Biological Resources Study: Canberra, Australia, 2003.

22. Gordon-Mills, E.; Womersley, H.B.S. The genus Chondria C. Agardh (Rhodomelaceae, Rhodophyta) in southern Australia. Aust. J. Bot. 1987, 35, 477-565. [CrossRef]

(C) 2019 by the authors. Licensee MDPI, Basel, Switzerland. This article is an open access article distributed under the terms and conditions of the Creative Commons Attribution (CC BY) license (http://creativecommons.org/licenses/by/4.0/). 